\title{
Pengaruh Tanggung Jawab Dan Konflik Terhadap Stres Guru Sekolah Dasar (SD) Negeri Se-Kecamatan Cileungsi Kabupaten Bogor
}

\author{
Erwin \\ Dosen STKIP Hermon Timika, Papua \\ Email: erwinjenta9@gmail.com
}

\begin{abstract}
The research was conducted to all teachers of elementary school districts Cileungsi regency of Bogor. By using a survey method with path analysis applied in testing hypothesis the number 80 teachers as sample was selected by using Slovin formula. Based on the results of data analysis in this research it is concluded: (1) the responsibility have negative direct effect to stress; (2) the conflict have positive direct effect to stress; (3) the responsibility have negative direct effect to conflict. The stress can be decreases through improvement of responsibility and to manage of conflict
\end{abstract}

Keywords: Stress, responsibility, and conflict

\section{PENDAHULUAN}

Sekolah dalam mencapai visi misinya, seringkali dihadapkan dengan masalah yang sangat kompleks diantaranya; masalah karakteristik guru yang tentunya memiliki karakter yang berbeda serta membutuhkan perlakukan yang berbeda pula. Apabila tidak dapat perlakuan yang sama maka guru akan memiliki tanggapan yang berbeda sehingga menganggap bahwa lingkungan mereka sudah tidak mendukung. Hal tersebut membuat guru menjadi stres, di samping itu guru juga akan mengalami stres yang tinggi apabila berhadapan dengan budaya sekolah yang tidak sesuai dengan prinsif mereka, sulitnya seorang guru dalam mengontrol pekerjaannya yang akan semakin membuat guru akan semakin terpuruk, ditengah-tengah masalah tersebut guru juga kerap kali mengalami pertentangan dengan pimpinan karena persoalan regulasi serta pertentangan dengan rekan kerja karena tugas dan fungsi yang sulit dilaksanakan dengan baik, oleh karena itu tanggung jawab sangat dibutuhkan dalam mengatasi persoalan yang dihadapi guru. stres kerap kali terjadi karena guru tidak mampu mengontrol pekerjaan dengan baik, stress juga dapat terjadi Karena adanya masalah yang dihadapi oleh guru di luar tugasnya sebagai guru. guru yang mengalami stres akan mengalami permasalahan- permasalahan pada dirinya seperti merasa gelisah, tidak merasa terbebani dengan aturan yang berlaku serta bisa berdmpak pada fisik guru seperti merasa capek, tegang di bagian leher, sakit perut dan susah tidur. " Maka dari itu peneliti ingin mengkaji secara ilmiah apakah tanggung jawab dan konflik berpengaruh terhadap stres.

\section{Stres}

Menurut Colquit (2009:141-142), "stress is defined as psychological respons to demands whan there is something at stake for individual and coping with those demands would taxes or exceeds a person's capacity or resourses". Stres didefinisikan sebagai respon spikologis yang diakibatkan oleh tuntukan fisik atau tuntutan lingkungan, dan sosial yang dinilai potensi membahayakan. Sehingga untuk mengatasinya diperlukan pengarahan kemampuan guru.

Sedangkan menurut Schermerhorn (35:2012), "stress is tension from extraordinary demands, constrains or opportunities stress as a state of tension experiented by individual facing extraordinary demands, constrains or opportunity". Schermerhorn mendefinisikan stres sebagai ketegangan yang berasal dari tuntutan, kendala atau peluang yang luar biasa. Stres merupakan keadaan ketegangaan yang dialami oleh individu dalam menghadapi 
tuntutan, kendala atau peluang yang luar biasa. jadi stres muncul akibat adanya tuntutan yang dihadapi pekerja dan kendala-kendala yang dilaluinya serta peluang yang dimilikinya.

Menurut McShane dan Glinov (2010:198), "stress is an adaptive respons to a situation that is perceived as challenging or threatening to a persons will beings. The stress respons is a complex emotional that produce psikological changes to prepare us for "fight or fight" to defend ourselves from the treath or flee from it. Stres adalah respon adaptif terhadap situasi yang dianggap menentang atau membahayakan kesejahteraan guru. Respon terhadap stres guru adalah emosi yang kompleks yang menghasilakan perubahan psikologi untuk mempersiapkan diri "bertarung “ dalam mepertahankan diri dari ancaman atau melarikan diri dari ancaman tersebut

Pengertian lain menurut Robbins (2013:595), "stress is a dynamic condition in which an individual is confronted with an opportunity, demand or resource related to what the individual desires and for which the outcome is perceived to be both uncertaint and important". Stres adalah suatu kondisi dinamis dimana seorang individu dihadapkan pada peluang, tuntutan atau sumber daya yang terkait dengan keinginan guru yang hasilnya dipandang tidak pasti dan penting.

Menurut Slocum (2011:221), "stress is the excitement, feeling of anxiety, and/or physical tension that occurs when the demands placed on an individual are though to exceed the person"s ability to cope". Stres adalah perasaan berlebihan, perasaan cemas dan ketegangan yang terjadi ketika tuntutan terhadap seseorang yang melebihan kemampuannya untuk melaksanakan. Selanjutnya menurut Wagner (2010:107), "Stress is an unpleasant emotional state that results when someone in uncertain of his or her capacity to resolve a perceived challenge to an important value". Stres merupakan keadaan emosional yang tidak menyenangkan yang terjadi ketika guru tidak yakin pada kemampuannya untuk menyelesaikan suatu tantangan terhadap nilai penting. Jadi stres pada diri guru timbul oleh kondisi emosi yang tidak stabil ketika kemampuan yang dimilikinya tidak sesuai dengan harapan

Luthan (2011:297) mengatakan bahwa, "stress is defined as an adaftive response to an external situation that result in physical, psychological and/or behavioral deviations for organizational perticipants". Stres diartikan sebagai respon adaptif terhadap situasi eksternal yang menghasilkan penyimpangan fisik, psikologis, dan atau perilaku pada anggota organisasi.

Berdasarkan penjelasan di atas maka sintesis stres adalah kondisi ketegangan yang dialami individu dalam menghadapi peluang, kendala, atau tuntutan berlebihan terhadap organisasi dengan indikator: perasaan cemas, khawatir, ketidak-senangan, lepas kendali, rasa lelah, dan rasa sakit.

\section{Tanggung Jawab}

Menurut Robbins (2013:271), "responsibility is the obligation or expectation to perform any assigned dutie". Tanggung jawab merupakan kewajiban atau harapan untuk melakukan setiap tugas yang diberikan. Tanggung jawab yang diberikan tentunya sesuai yang telah ditetapkan sehingga dapat memaksimalkan tugas yang telah diberikan.

Menurut Daft (2010:246), "responsibility is the duty to perform the task or activity an employeehas been assigned". Tanggung jawab merupakan kewajiban untuk melakukan tugas atau kegiatan yang telah ditatapkan.

Griffin dan Moorhead (2007:48), "responsibility is an obligation to do something with the expectation of achieving some act output". Tanggung jawab adalah kewajiban untuk melakukan sesuatu dengan harapan mencapai beberapa tindakan atau output

Selanjutnya menurut Schermerhorn (2010:89) bahwa, "responsibility is sense of accountability, pursuit of excellence, self restrain". Dalam definisi tersebut dijelaskan bahwa rasa tanggung jawab, mengejar keunggulan, pengendalian diri juga merupakan bentuk rasa tanggung jawab. 
Hal senada di ungkapkan oleh Newstroom (2011:38), "responsibility is employee discipline themselves for performance on the team in the team in the same way that the members of a football team discipline themselves to training standars and the rules of the game". Tanggung jawab adalah disiplin pegawai dalam meningkatkan kinerja bersama tim seperti pemain bola yang mengikuti standar aturan kedisiplinan dalam bermain.

Berdasarkan uraian di atas maka sintesis tanggung jawab adalah sikap dan perilaku untuk senantiasa melaksanakan tugas dan kewajiban yang diemban secara sungguhsungguh dan benar/tepat dengan indikator: kesediaan untuk melaksanakaan tugas sampai tuntas, kesediaan untuk memperbaiki kesalahan, kesediaan untuk menerima teguran dari pimpinan, kesediaan untuk menerima arahan dari pimpinan dan bertindak dengan teliti.

\section{Konflik}

Menurut Kreitner (2010:373), "conflict is a complex subject for several reasons. Primary among them is the reality that conflict often carries a lot of emotional luggage. Fear of losing or fear of change quickly raises the emotional stakes in a conflict. Conflicts also vary widely in magnitude". Dalam hal ini, konflik merupakan pokok kajian yang kompleks karena beberapa alasan, diantaranya adalah kenyataan bahwa konflik sering membawa banyak muatan emosi. Ketakutan kehilangan atau ketakutan perubahan segera memunculkan luapan emosi dalam suatu konflik. Konflik juga bisa beragam bentuknya. Hal ini mengisyaratkan bahwa konflik bukan persoalan sederhana, melainkan satu hal yang kompleks dan multidimensional.

Sedangkan menurut Robbins (2012:382), "conflict is Perceived incompatible differences resulting in some form of interference or opposition. Konflik dianggap perlainan kompatibel yang mengakibatkan beberapa bentuk gangguan atau oposisi.

Menurut Newstrom (2011:288), "conflict is an interpersonal process that arises from disagreements over the goals to attain, the methods to be used to accomplish those goals, or even the tone of voice used as people express their position". Konflik merupakan proses dalam pencapaian tujuan yang menimbulkan perselisihan dan terjadi karena adanya perlainan tujuan yang ingin dicapai. Selain itu konflik terjadi apabila metode dan bahkan intonasi suara yang digunakan oleh orang yang berkepentingan dipandang tidak sesuai atau tidak pantas.

Sedangkan menurut McShane (2010:370), "conflict is a prosess in which one party perceives that his or her interests are being opposed or negatively affected by another party". Hal tersebut dapat diartikan bahwa konflik adalah proses di mana satu pihak merasakan bahwa kepentingannya sedang menentang atau negatif dipengaruhi oleh pihak lain

Lebih lanjut dijelaskan oleh Robbins (2012:466), "conflict, then, as a process that begins when one party perceives that another party has negatively affected, or is about to negatively affect, something that the first party cares about. This definition is purposely broad. It describes that point in any ongoing activity when an interaction "crosses over" to become an interparty conflict. It encompases the wide range of conflicts that people experience in organizations-incompatibility of goals, differences over interpretations of facts, disagreements based on behavioral expectations, and the like". Konflik merupakan proses yang dimulai ketika satu kelompok melihat kelompok lain berpengaruh negatif, atau akan berpengaruh negatif. Hal ini mengisyaratkan bahwa tekanan dalam aktivitas yang berlangsung ketika interaksi "saling bersilang" menjadi konflik antar kelompok, mencakup serangkaian konflik yang dialami orang dalam organisasi, ketidakcocokan tujuan, perlainan tentang interpretasi fakta, perdebatan atas dasar harapan tingkah laku, dan sebagainya. Dengan demikian, mencakup seluruh rangkaian tingkat konflik dari tindakan 
berlebihan dan kasar sampai bentuk permusuhan halus

Menurut McShane dan Glinow (2010:370), "conflict is proses in party perceives that its interest are being opposed or negatife affected by another party". Konflik adalah dimana satu pihak merasakan bahwa menerima penentang ata efek negatif oleh pihak lainnya. Proses dari konflik dijelaskan sebagai baerikut:

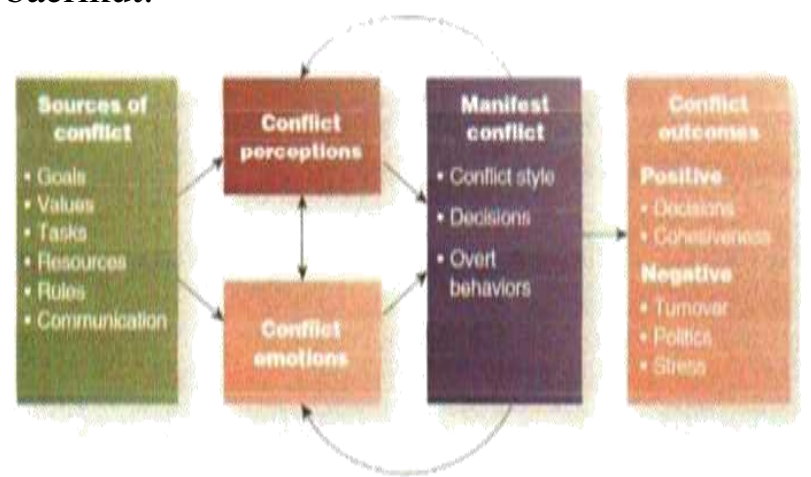

Gambar 2.1:The conflict Proses.

Berdasarkan ilustrasi gambar di atas, mengenai proses terjadinya konflik, dimulai dengan tujuan terjadinya conflict yang tidak kompatibel, perbedaan nilai- nilai, dan kondisi lainnya yang menyebabkan satu atau kedua belah pihak merasakan bahwa sedang terjadi konflik.

Berdasarkan uraian di atas maka sintesis konflik adalah ketidaksepahaman atau pertentangan yang terjadi dalam suatu organisasi ketika perilaku guru terhambat oleh perilaku orang lain dengan indikator: Perbedaan persepsi, Perbedaan tujuan, Pihak oposisi dan Ketidakcocokan.

\section{METODE PENELITIAN}

Penelitian ini dilaksanakan pada guru Sekolah Dasar (SD) Negeri Se-Kecamatan Cileungsi Kabupaten Bogor dilaksanakan selama 3 (tiga) bulan. Metode yang digunakan dalam penelitian ini adalah survey dengan menggunakan teknik kausal. Populasi adalah guru Sekolah Dasar (SD) Negeri Se-Kecamatan Cileungsi Kabupaten Bogor yang berjumlah 100 guru dengan jumlah sampel sebanyak 80 guru. Data yang dikumpulkan dalam penelitian dijaring melalui kuesioner yang berupa skala penilaian (rating scale) dengan sebaran skor antara 1 sampai dengan 5 .

Setelah dilakukan analisis deskriptif dilanjutkan dengan uji persyaratan analisis berupa uji normalitas, uji linearitas data dan keberartian regresi, dilakukan uji hipotesis dengan menggunakan teknik analisis jalur (path analysis).

\section{HASIL DAN PEMBAHASAN \\ Pengaruh Langsung Tanggung Jawab terhadap Stres}

Hasil penelitan ini menunjukkan bahwa tanggung jawab memberikan pengaruh negatif secara langsung terhadap stres. Besarnya pengaruh tersebut ditunjukkan oleh koefisien korelasi $-0,649$ dan koefisien jalur -0,487. Hal ini menujukkan bahwa tanggung jawab dapat menurunkan stres guru.

Hasil penelitian ini sejalan dengan pendapat Menurut McShane \& Glinow (2010:204), "the degree to which low task control is a stressor increases with the burden of responsibility the employee must carry. Assembly line workers have low task control, but their stress can be fairly low if their level of responsibility is also low". Tingkat kontrol tugas membuat orang semakin stres seiring dengan beban tanggung jawab yang diembannya. Para pekerja yang kurang kontrol terhadap tugas-tugasnya akan tetapi stres mereka bisa ringan kalau tanggung jawabnya juga ringan.

Hal senada diungkapkan oleh Kerzner (2010:278), "the factors that serve to make any occupation especially stressful are responsibility with out the outhority or ability to exert control, a necessity for perfection, the pressure of deadlines, role ambiguity, role conflict, role overload the crossing of organizational boundaries, responsibility for the actions of subordinates. Faktor yang menyebabkan suatu jabatan membuat guru stres itu karena tanggung jawab yang diembannya tidak dibarengi dengan otoritas atau kemampuan untuk mengontrol, kemudian tidak dibarengi dengan konsep berpikir perfeksionis, juga tidak dibarengi dengan kerja di bawah 
tekanan, peran ambiguitas, peran konflik, dan tantang ikatan antar organisasi, dan tidak dibereng dengan bertanggungjawab terhadap bawahan).

Guru yang senantiasa menganggap bahwa pekerjaan adalah suatu kewajiban yang harus dilaksanakan terkadang membuatnya merasa tertekan karena tuntuntan untuk melaksanakan kewajiban tersebut. Akan tetapi apabila guru menganggap bahwa beban yang diembannya adalah suatu kebutuhan yang harus dilaksanakan dengan baik serta mengaggap hal tersebut merupakan kehormatan bagi mereka maka tentunya guru akan melaksanakan kewajiban tersebut dengan baik tanpa adanya perasaan ditekan atas dasar tuntutan.

Lebih lanjut Robbins (2012:187) mengatakan bahwa, "when you take a test at school or have your annual performances review at work, you feel stress because you confront opportunity, constraints and demands. A good performances review may lead to a promotion, greater responsibilities, and a higher salary". Ketika anda akan melakukan tes atau kegiatan tahunan, anda akan merasa stres justru karena melawan kesempatan, halangan dan tuntutan. Padahal anda tidak menyadari bahwa dengan melakukan tes dan kegiatan tahunan itu, justru akan membawa pada kenaikan jabatan anda sendiri, juga tanggung jawab yang lebih besar, dan bahkan gaji yang lebih tinggi.

Apabila guru menghadapi masalah dan menghidar dari masalah tersebut maka justru akan menjauhkan diri sendiri dari kesempatan yang baik, kesempatan akan hilang padahal apabila guru mampu berproses dalam situasi yang meruapakan bentuk keniscayaan dalam sebuah organisasi maka akan berdampak positif terhadap karir, jabatan dan bahkan gaji lebih tinggi.

Lebih lanjut diungkapkan oleh George \& Jones (2012:251) bahwa, "five major potential stressors, or sources of stress, are personal life, job responsibilities, membership in work groups and organizations, work - life balances, and environment mental uncertainty". Ada lima hal yang berpotensi menjadi sumber stres, hal-hal yang dimaksud adalah: kehidupan pribadi, tanggung jawab pekerjaan, menjadi bagian dalam kelompok tim organisasi, keseimbangan antara pekerjaan dan kehidupan itu sendiri serta lingkungan mental yang tidak jelas.

\section{Pengaruh Langsung Konflik terhadap Stres}

Hasil penelitan ini menunjukkan bahwa konflik memberikan pengaruh positif secara langsung terhadap stres. Besarnya pengaruh tersebut ditunjukkan oleh koefisien korelasi 0,581 dan koefisien jalur 0,363 Hasil penelitian ini sejalan dengan pendapat Menurut McShane \& Glinow (2010:329), "the degree to which low task control is a stressor increases with the burden of responsibility the employee must carry. Assembly line workers have low task control, but their stress can be fairly low if their level of responsibility is also low". Tingkat kontrol tugas membuat orang semakin stres seiring dengan beban tanggung jawab yang diembannya. Para pekerja yang kurang kontrol terhadap tugas-tugasnya akan tetapi stres mereka bisa ringan kalau tanggung jawabnya juga ringan.

Lebih lanjut diungkapkan oleh McShane/Von Glivon (256),"for both man and women, work to family conflict was found to be linked to job satisfaction, turnover intention dan stress, while family to work conflict resulted in stress and absentee in". Baik pria maupun wanita konflik yang dialami dalam keluarga sangat mempengaruhi tingkat kepuasan kerja juga dapat mengalihkan perhatian dan menjadi stres, sementara bekerja dalam suasan konflik justru mengakibatkan stres dan kemangkiran).

\section{Pengaruh Langsung Tanggung Jawab terhadap Konflik}

Hasil penelitan ini menunjukkan bahwa tanggung jawab memberikan pengaruh negatif secara langsung terhadap konflik. Besarnya pengaruh tersebut ditunjukkan oleh koefisien korelasi -0,446 dan koefisien jalur -0,446. Hasil penelitian ini sejalan dengan yang diungkapkan Batemen \& Snell (2015:486), "many factors 
cause great potential for descriptive conflik: the sheer number and variety of contacts, ambiguities in jurisdiction and responsibilities, different in goals, competition for scare resources, different perpectives held by members of different units, varying time horizons in which some units attent to longterm consideration and others focus on shortterm needs, and others". Banyak faktor yang sangat berpotensi munculnya konflik yang destruktif seperti: hubungan yang beragam, ambigu dalam tanggung jawab, perlainan tujuan, kompetisi/persaingan tidak sehat, perspektif yang berlain dari unit yang berlain pula, beragamnya waktu dari setiap unit kerja, baik hal pertimbangan jangka panjang maupun jangka pendek yang dibutuhkan, dan lain-lain.

Lebih lanjut dijelaskan oleh Kinicki \& William (2009:424), "that's not my job and those aren't my responsibilities". "those resources belong to me because I need them as part of may job". "When task responsibilies are unclear that can often lead to conflict". Banyak orang berkata bahwa itu bukan pekerjaan dan tanggung jawab saya, ada juga yang berkata bahwa semua hal itu adalah bagian hidup saya, karena saya memerlukan semua itu sebagai bagian dari hidup saya. Ketika tanggung jawab pekerjaan tidak jelas maka hal itu justru mengakibatkan konflik

Lessem \& Palsule (2005:260) bahwa,"social reality, which is partly where CEO Chris Mellor is Coming From, is a more humanistic view of the world, an acceptances of different viewpoints, histories and moral codes, as well as the conflict which such acceptances engender. unitary reality, for an agent of change, is reflect in responsibility and outhority, consistency and conservation, which is the other part of chris Mellor's orientation". Dalam realitas sosial dimana Khris Mellor adalah sorang CEO, dia dia seorang yang humanis cara pandang terhadap dunia, dia juga orang berterima atau menghargai perlainan pandangan, dia juga seorang yang historis dan menjaga kode etik, dalam realitanya, Khris Mellor adalah seorang agen perubahan dan juga sangat tanggap dengan tanggung jawab dan otoritas, dia sangat konsisten dan konservatif)

Dalam studi realitas di atas, ditemukan bahwa: Guru yang konsisten dan menghargai perlainan cenderung mengalami pertentangan ataupun konflik karena orang dia memahami dirinya sendiri dan orang lain serta memahami tanggung jawabnya sebagai makhluk sosial yang tidak bisa terlepas dari bantuan orang lain. Dengan mengedepankan tolenransi antar umat dan antar sesame, maka akan menumbuhkan saling percaya, kerjasama, dan kenyamanan dalam bekerja atau menjalani hidup dalam kehidupan sosial. Orang yang cerdas akan senantiasa menempatkan segala sesuatu pada tempatnya.

Menurut Batemen dan Snell (2015:97), "contructive conflict does not need to be generated on such a formal basis and os not solely the leader's responsibility". Konflik yang sifatnya konstruktif, sebenarnya tidak perlu dimunculkan dalam situasi yang formal dan hal itu bukan semata-mata tanggung jawab pemimpin. Tanggung jawab yang ada dalam sebuah organisasi tidak semestinya dilimpahkan sepenuhnya kepada atasan karena itu adalah tanggung jawab bersama serta masalah yang biasa dan bisa diselesaikan dengan jalan damai dan kekeluargaan tidak mesti di komunikasi dalam forum/rapat formal, disinilah akan terlihat bagaimana kedewasaan kita dalam bekerja serta menginyakapi sesuatu dengan baik.

\section{KESIMPULAN}

Kesimpulan: (1) Tanggung jawab berpengaruh langsung negatif terhadap stres guru. Artinya, semakin tinggi tingkat tanggung jawab guru maka akan semakin rendah stres guru Sekolah Dasar (SD) Negeri Se-Kecamatan Cileungsi Kabupaten Bogor. (2) Konflik berpengaruh langsung positif terhadap stres guru. Artinya, semakin tinggi konflik maka akan mengakibatkan peningkatan stres guru Sekolah Dasar (SD) Negeri Se-Kecamatan Cileungsi Kabupaten Bogor. (3) Tanggung jawab berpengaruh langsung negatif terhadap konflik guru. Artinya, semakin tinggi tingkat 
tanggung jawab maka akan semakin rendah konflik guru Sekolah Dasar (SD) Negeri SeKecamatan Cileungsi Kabupaten Bogor.

Saran: saran - saran untuk guru. diharapkan dapat meningkatkan tanggung jawab cara-cara sebagai berikut: (1) kesadaran guru dalam melakukan tindakan (conscientiousness), (2) keramahan guru dalam bersikap (agreeabieness), (3) tingkat kenyamanan guru dalam bekerja (extraversion), (4) stabilitas emosional guru dalam mengahadapi masalah (neuroticism), (5) guru harus terbuka terhadap hal-hal baru (openness to experience) dan (6) kemampuan guru dalam mengontrol tugas Kedua, saran untuk guru terkait dengan konflik agar dapat menurunkan stres adalah: (1) guru senantiasa mengintrospeksi diri, (2) cepat tanggap dalam melihat isu-isu strategis, (3) guru harus mempu mengelola konflik dengan baik serta harus mengetahui konsep managemen konflik,. Hal tersebut akan memudahkan guru dalam menyelesaikan persolan yang dihadapi guru terkhusus yang akan berdampak pada pertikaian antar sesama.

\section{DAFTAR PUSTAKA}

Jason A. Colquit, Jeffrey A. Lepine dan Michael J. Wesson, Organizational Behavior: Improve performance and comitment in workplace. New York: McGraw Hill 2009

Jennifer M.George \& Gareth R. Jones. Understanding and Managing Organizational Behavior, Sixth Edition. New York: Pearson, Prentice-Hall 2012).

John R Schermerhorn, Jr, James Hunt, Richar $\mathrm{N}$, Osborn, Organizational Behavior. New Jersey: John Wiley \& Son Inc, 2010

John W. Newstrom, Organizational Behavior, Human Behavior at Work, $13^{\text {th }}$ Edition. New York: McGraw-Hill, 2011

Kinicki/Williams. Management, Fourth Edition. New York: McGraw-Hill/Irwin Companies, Inc, 2009
Richard L. Daft, New Era Of Management. South Western:Cengage learning,2010

Ricky W. Griffin, Gregory Moorhead, Organizational Behavior, Eleventh Edition, Managing people and organizations. South western : cengage leraning, 2012

Robert Kreitner and Angelo Kinicki, Organizational Behavior. New York: McGraw- Hill Irwin, 2010

Steven L. McShane. Mary Ann Von Glinow. Organizational Behavior: emerging Knowladge and practice for the real world $5^{\text {th }}$ ed. New York : McGraw Hill Compenies Inc, 2010

Stephen P. Robbins dan Mary Coulter, Management. New Jersey: Pearson education.2012.

Stephen Robbin \& Timothy Judge, Organizational Behavior. New York : Pearson, 2013. 